\title{
Chemical Composition, Antioxidant Activity, and Antifungal Effects of Essential Oil from Laurus nobilis L. Flowers Growing in Morocco
}

\author{
Ibrahim Mssillou ${ }^{D},{ }^{1}$ Abdelkrim Agour ${ }^{D},{ }^{1}$ Asmae El Ghouizi ${ }^{D},{ }^{1}$ \\ Noureddine Hamamouch $\mathbb{D}^{2}{ }^{2}$ Badiaa Lyoussi $\mathbb{D}^{1},{ }^{1}$ and Elhoussine Derwich $\mathbb{D}^{1,3}$ \\ ${ }^{1}$ Laboratory of Natural Substances, Pharmacology,Environment, Modeling,Health and Quality of Life (SNAMOPEQ), \\ University of Sidi Mohamed Ben Abdellah, Fez 30000, Morocco \\ ${ }^{2}$ Laboratory of Plant Physiology and Biotechnology, Faculty of Sciences, University Mohamed V, Rabat, Morocco \\ ${ }^{3}$ Unity of GC/MS and GC-FID, City of Innovation, University of Sidi Mohamed Ben Abdallah, Fez 30000, Morocco
}

Correspondence should be addressed to Badiaa Lyoussi; lyoussi@gmail.com

Received 21 June 2020; Revised 29 November 2020; Accepted 18 December 2020; Published 31 December 2020

Academic Editor: Jorge Barros Vel zquez

Copyright (c) 2020 Ibrahim Mssillou et al. This is an open access article distributed under the Creative Commons Attribution License, which permits unrestricted use, distribution, and reproduction in any medium, provided the original work is properly cited.

\begin{abstract}
In this study, the chemical composition and the antioxidant and antifungal activities of essential oil from Laurus nobilis flowers were examined. The essential oil was prepared using steam distillation in a modified Clevenger-type apparatus. The chemical composition of the obtained essential oil and chemotypes was determined using gas chromatography coupled with mass spectrometry (GC/MS) and gas chromatography with flame ionization detection (GC-FID). Twenty-five volatile compounds were identified, which made up $92.07 \%$ of the total essential oil content. The essential oil yield was $1.06 \%$ and the most abundant compounds were 1.8-cineole (45.01\%), $\alpha$-caryophyllene (7.54\%), germacradienol (6.13\%), limonene (4.69\%), $\alpha$-pinene (3.04\%), and germacrene $\mathrm{D}(3.14 \%)$. The antifungal activity of the obtained essential oil was tested against seven fungal strains: Aspergillus clavatus, A. niger, Chaetomium globosum, Cladosporium cladosporioides, Myrothecium verrucaria, Penicillium citrinum, and Trichoderma viride. The results indicated that essential oil from L. nobilis flowers exhibited significant antifungal activity against the tested fungal strains with minimum inhibitory concentrations (MICs) ranging from 0.05 to $0.46 \mathrm{mg} / \mathrm{mL}$. The essential oil of L. nobilis also exhibited strong total antioxidant capacity (TAC) as indicated by its ability to scavenge free radical DPPH. Taken together, this study indicates that the essential oil from L. nobilis flowers possesses significant antifungal and antioxidant activities, possibly due to the high level of 1,8-cineole.
\end{abstract}

\section{Introduction}

Herbs and spices have been used for generations, not simply as food ingredients but also to treat a plethora of ailments and, in recent times, scientific data are accumulating that demonstrate, for many spices and related essential oils, medicinal properties useful in the prevention of diseases or the relief of their symptoms. In fact, many natural compounds extracted from plants have demonstrated biological activities, notably antibacterial, antifungal, and antioxidant properties. The antimicrobial properties of plant volatile oils and their constituents from a wide variety of plants have been documented $[1,2]$. The Lauraceae comprises 32 genera and about 2.500 species. Laurel (Laurus nobilis L.) is a plant native to the southern Mediterranean region. It is an evergreen tree cultivated in many warm regions of the world, particularly in the Mediterranean countries (Turkey, Greece, Spain, Portugal, and Morocco). In Europe and the USA, L. nobilis is widely cultivated as an ornamental plant [3].

Essential oils are valuable natural products used as raw materials in perfumes, cosmetics, aromatherapy, phytotherapy, spices, and nutrition [4]. The leaves of L. nobilis have been used to treat Neuralgia and Parkinsonism [5], while the essential oil obtained from the leaves of this plant 
has been used for relieving hemorrhoid and rheumatic pains and has been used to treat epilepsy [6]. The chemical composition of the volatile fraction of $L$. nobilis as well as the composition and bioactivities of the alcoholic and nonpolar extracts has been studied extensively [7-9]. Intensive research has been conducted on this species [10-12]. The antifungal activity of essential oil extracted from L. nobilis has been documented $[13,14]$, the oil presents a low minimum inhibitory concentration and is rich in monoterpenes and sesquiterpenes. Essential oils have been shown to possess antibacterial, antifungal, antiviral, insecticidal, antidiarrheal, and antioxidant properties [15-19]. There is currently an increased interest in looking at antimicrobial properties of extracts from aromatic plants particularly essential oils [20]. Essential oils are a rich source of biologically active compounds; they have been used in cancer treatment [21] and food preservation [22]. The chemical composition and antimicrobial properties of essential oils extracted from diverse plant species have been demonstrated using a variety of experimental methods [23, 24]. However, to the best of our knowledge, the chemical composition, antioxidant activity, and antifungal effects of essential oil from L. nobilis flowers in Morocco have not been studied.

The objective of this study was to identify the chemical compounds and examine the antioxidant and antifungal activities of essential oil from $L$. nobilis flowers.

\section{Materials and Methods}

2.1. Chemicals and Standards. All solvents used in this study were of analytical grade unless otherwise specified. Hexane solution, methanol, sulfuric acid, anhydrous sodium sulfate, series of alkanes $\left(\mathrm{C}_{4}-\mathrm{C}_{28}\right)$ standards, and 1,1-diphenyl-2-picrylhydrazyl (DPPH) radical were purchased from Sigma-Aldrich (St. Louis, MI, USA). The fungal strains were obtained from the Microbiology Laboratory, Faculty of Medicine and Pharmacy, Fez, Morocco.

2.2. Collection and Preparation of the Plant Material. The flowers of L. nobilis were collected in July 2019, from the Middle Atlas mountains in Morocco, a region where people frequently use this plant for therapeutic uses [25]. The region is located $15 \mathrm{~km}$ southeast of Boulemane city (latitude: $25^{\circ} 31^{\prime} 11^{\prime \prime}$; longitude: $5^{\circ} 22^{\prime} 21^{\prime \prime}$; altitude: $2100 \mathrm{~m}$ ); it is characterised by semidesertic climate with strong continental influence, and an annual average temperature of $20^{\circ} \mathrm{C}$. The collected flowers were air-dried for sixteen days and stored in the laboratory, at the Faculty of Sciences, University Sidi Mohamed Ben Abdellah, Fez, Morocco.

2.3. Essential Oil Extraction. The essential oil was extracted by hydrodistillation using an apparatus of Clevenger type as previously described [26, 27]; briefly, $200 \mathrm{~g}$ of L. nobilis flowers were mixed in $1.4 \mathrm{ml}$ of distilled water for 2.5 hours. The yellowish oil $(0.5 \mathrm{ml})$ was dissolved in hexane and then dried over anhydrous sodium sulfate. After filtration, the solvent was eliminated by pressure distillation reduced in a rotary evaporator at $35^{\circ} \mathrm{C}$, and the extracted oil was stored at $4^{\circ} \mathrm{C}$ in obscurity until analysis.

The amount of oil obtained was calculated as follows:

$$
\text { oil }(\% \mathrm{v} / \mathrm{w})=\frac{\text { observed volume of oil }(\mathrm{ml})}{\text { weight of the sample }(\mathrm{g})} \times 100 \text {. }
$$

2.4. Gas Chromatography (GC/MS and GC-FID) Analysis. The chemical composition of the oil extracted from L. nobilis flowers was determined by GC-MS (Trace GC ULTRA, Thermo Fischer, France) using a Varian capillary column (CP-Sil 5CB, $50 \mathrm{~m}$ length, $0.32 \mathrm{~mm}$ of diameter, and Film thickness $1.25 \mu \mathrm{m}$ ). The column temperature was programmed from $40^{\circ} \mathrm{C}$ to $280^{\circ} \mathrm{C}$ for $5^{\circ} \mathrm{C} / \mathrm{min}$. The temperature of the injector was fixed to $250^{\circ} \mathrm{C}$ and one of the detectors (FID) to $260^{\circ} \mathrm{C}$. The debit of the gas vector (nitrogen) was fixed to $1 \mathrm{ml} / \mathrm{min}$. The volume of the injected specimens was $0.5 \mu \mathrm{l}$ of diluted oil in hexane solution (10\%). The percentage of each constituent in the oil was determined by area peaks.

The essential oil was subjected to GC-FID analysis (Polaris Q, Thermo Fischer, France) using the same type of column used for GC-MS (the constituents of essential oil were identified in comparison with their Kovats index, calculated concerning the retention time of a series of linear alkanes $\left(\mathrm{C}_{4}-\mathrm{C}_{28}\right)$ with those of reference products and in comparison with their Kovats index with those of the chemical components gathered in [28], in comparison with their specters of mass with those gathered in a library of (NIST-MS) type.

2.5. Fungal Strains. The antifungal activity of the essential oil prepared from $L$. nobilis flowers was evaluated by measuring the zone of inhibition and the minimal inhibition concentration (MIC). Values were calculated according to published procedures $[29,30]$ with minor modifications.

Antifungal tests were then carried out by the disc diffusion method [31], using $50 \mu \mathrm{l}$ of suspension containing 52 spores/ml of fungi spread on potato dextrose agar (PDA). The discs ( $6 \mathrm{~mm}$ in diameter) were impregnated with $10 \mu \mathrm{l}$ of essential oil and placed on the inoculated agar. Negative controls were prepared using the same solvents used to dissolve the plant extract. Ofloxacin $(20 \mu \mathrm{g}$ per disc) and sulbactam $(30 \mu \mathrm{g})+$ cefoperazone $(70 \mu \mathrm{g})(100 \mu \mathrm{g} / \mathrm{disc})$ were used as positive reference standards to determine the sensitivity of one strain/isolate in each microbial species tested. The inoculated plates were incubated at $27^{\circ} \mathrm{C}$ for $72 \mathrm{~h}$. The fungal strains tested were Aspergillus clavatus, A. niger, Chaetomium globosum, Cladosporium cladosporioides, Myrothecium verrucaria, Penicillium citrinum, and Trichoderma viride., and assays were performed in duplicate.

\subsection{In Vitro Free Radical Scavenging Assays}

2.6.1. DPPH Radical Scavenging Activity. The ability of the essential oil to scavenge the DPPH radical was tested as previously described [32]; $100 \mu \mathrm{l}$ of different concentrations of the essential oil was added to $750 \mu \mathrm{l}$ of an ethanolic 
solution containing $0.1 \mathrm{mmol}$ of DPPH (2,2-diphenyl-1 picrylhydrazyl). Mixtures were incubated at room temperature for $30 \mathrm{~min}$ in dark. The absorbance of the mixture was then measured at $517 \mathrm{~nm}$ using a spectrophotometer (UV2005. J.P. SELECTA. s.a) and the percentage of inhibition (PI) was calculated using the following equation:

$$
\operatorname{PI}(\%)=\left(1-\left(\frac{A_{s}}{A_{c}}\right)\right) * 1000,
$$

where $A_{\mathrm{c}}$ is the absorbance of the negative control and $A_{\mathrm{s}}$ is the absorbance of the sample. Butylated hydroxytoluene (BHT) and ascorbic acid served as positive controls for maximal radical quenching. The $\mathrm{IC}_{50}$ values were calculated as the concentration causing $50 \%$ inhibition of DPPH radical.

2.6.2. Total Antioxidant Capacity (TAC). Total antioxidant capacity was measured as previously described [33]. Different volumes $(100 \mu \mathrm{l}, 50 \mu \mathrm{l}$, and $25 \mu \mathrm{l})$ of the essential oil were mixed in $1 \mathrm{ml}$ of reactive solution $(0.6 \mathrm{M}$ sulfuric acid, $28 \mathrm{mM}$ sodium phosphate, and $4 \mathrm{mM}$ ammonium molybdate.) After incubation at $95^{\circ} \mathrm{C}$ for 90 minutes, the optical density at $695 \mathrm{~nm}$ was measured using a spectrophotometer, with a blank containing methanol instead of the essential oil. The antioxidant capacity was expressed in milligrams of ascorbic acid equivalent per gram of extracts (Mg EAA/g extracts). Ascorbic acid was used to make a standard curve.

\section{Results}

3.1. Phytochemical Analysis. The constituents of essential oil L. nobilis flowers are listed in order of their elution on the CP-Sil 5CB column (Figure 1). The yield of the obtained essential oil was $1.06 \%$ and contained 25 compounds, which made up $92.07 \%$ of the total essential oil. The most abundant constituents were 1.8 -cineole $(45.01 \%), \alpha$-caryophyllene (7.54\%), germacradienol (6.13\%), limonene (4.69\%), $\alpha$-pinene $(3.04 \%)$, and germacrene D (3.14\%) (Table 1).

3.2. Antifungal Activity. The antifungal activity of the essential oil extracted from the flowers of $L$. nobilis was tested against Aspergillus clavatus, A. niger, Chaetomium globosum, Cladosporium cladosporioides, Myrothecium verrucaria, Penicillium citrinum, and Trichoderma viride. The obtained results are presented in (Table 2).

The disc diffusion assay indicated that the inhibition zone of the essential oil ranged between $6.05 \mathrm{~mm}$ and $19.25 \mathrm{~mm}$, depending on the fungal strain tested. The strongest inhibition zone was observed for A. clavatus followed by A. niger and C. globosum, indicating the sensitivity of these strains to the essential oil from L. nobilis flowers. The MIC values obtained for these strains were $0.05,0.14$, and $0.18 \mathrm{mg} / \mathrm{mL}$, respectively. The other fungal strains tested were also sensitive to the essential but to a lesser extent.

\subsection{Antioxidant Activity}

3.3.1. DPPH Radical Scavenging Activity. The antioxidant activity of the extracted essential oil was determined based on its ability to reduce the free radicals DPPH. The essential oil from $L$. nobilis flowers exhibited strong power of reducing $\mathrm{DPPH}\left(\mathrm{IC}_{50}=82.01 \pm 0.002 \mu \mathrm{g} / \mathrm{ml}\right)$, compared to BHT $\quad\left(\mathrm{IC}_{50}=7.71 \pm 0.0001\right)$ and ascorbic acid $\left(\mathrm{IC}_{50}=1.16 \pm 0.0001 \mu \mathrm{g} / \mathrm{ml}\right.$ ) (Table 3). A low inhibitory concentration is an indication of a high scavenging activity. A substance can be considered as an antioxidant if its $\mathrm{IC}_{50}$ does not exceed $5 \mathrm{mg} / \mathrm{ml}$ [34]. In this study, the essential oil of $L$. nobilis has proven its ability as a strong antioxidant; this is accordance with previous reports $[35,36]$. In fact, the major compound of the essential oil, 1.8-cineole (45.01\%), has been shown to have strong antioxidant capacity [37].

3.3.2. Total Antioxidant Activity. The total antioxidant capacity was determined by the method of phosphomolybdenum, based on the reduction of Mo (VI) to Mo (V) by the antioxidant substance [38], and the values were expressed as ascorbic acid equivalents per gram (AAE/g) (Figure 2). For the different volumes of the essential oil used $(100 \mu \mathrm{l}, 50 \mu \mathrm{l}$, and $25 \mu \mathrm{l}$ ), the total antioxidant activities obtained were $796.74 \pm 3.53 \mathrm{AAE} / \mathrm{g}), \quad(568.91 \pm 96.16 \mathrm{AAE} / \mathrm{g}), \quad$ and (440.91 $\pm 10.37 \mathrm{AAE} / \mathrm{g})$, respectively, indicating a positive correlation between the volume of the essential oil used and the level of antioxidant activity.

\section{Discussion}

4.1. Phytochemical Analysis. In this study, the yield of the essential oil obtained from the hydrodistillation of the flowers of $L$. nobilis was high (1.06\%) compared to other plants such as Artemisia herba-alba (0.59\%), A. absinthium (0.57\%), A. pontica (0.31\%) [39], Pseudotsuga menziesii (0.67\%), Pistacia lentiscus (1.02\%) [40], Lavandula angustifolia (0.8-2.8\%), Mentha spicata (0.5-1\%), and Citrus aurantium (0.5-1\%) [41], but lower compared to Eucalyptus grandis (4.7\%) [42] and E. globulus (1.21\%) [43]. These differences might be due to harvest time and local, climatic, and seasonal factors as well as the storage duration of the medicinal plant used. 1,8-Cineole was the main component present in the essential oil, with other compounds being present in low percentage or even in traces; this is in accordance with the previously published report. 1.8-Cineole was identified as the major component in essential oils obtained from L. nobilis in different countries [44-52]. In addition, 1.8-cineole was also identified as the major component in other plants, such as Origanum minutiflorum [53] and Callistemon speciosus [54]. The essential oil composition showed a pattern similar to those published for other geographical regions, including a high level of 1.8-cineole [55-60]. The essential oil content varies depending on the geographical origin of the plant, but also on the plant part used for extracting the essential oil [61]. 


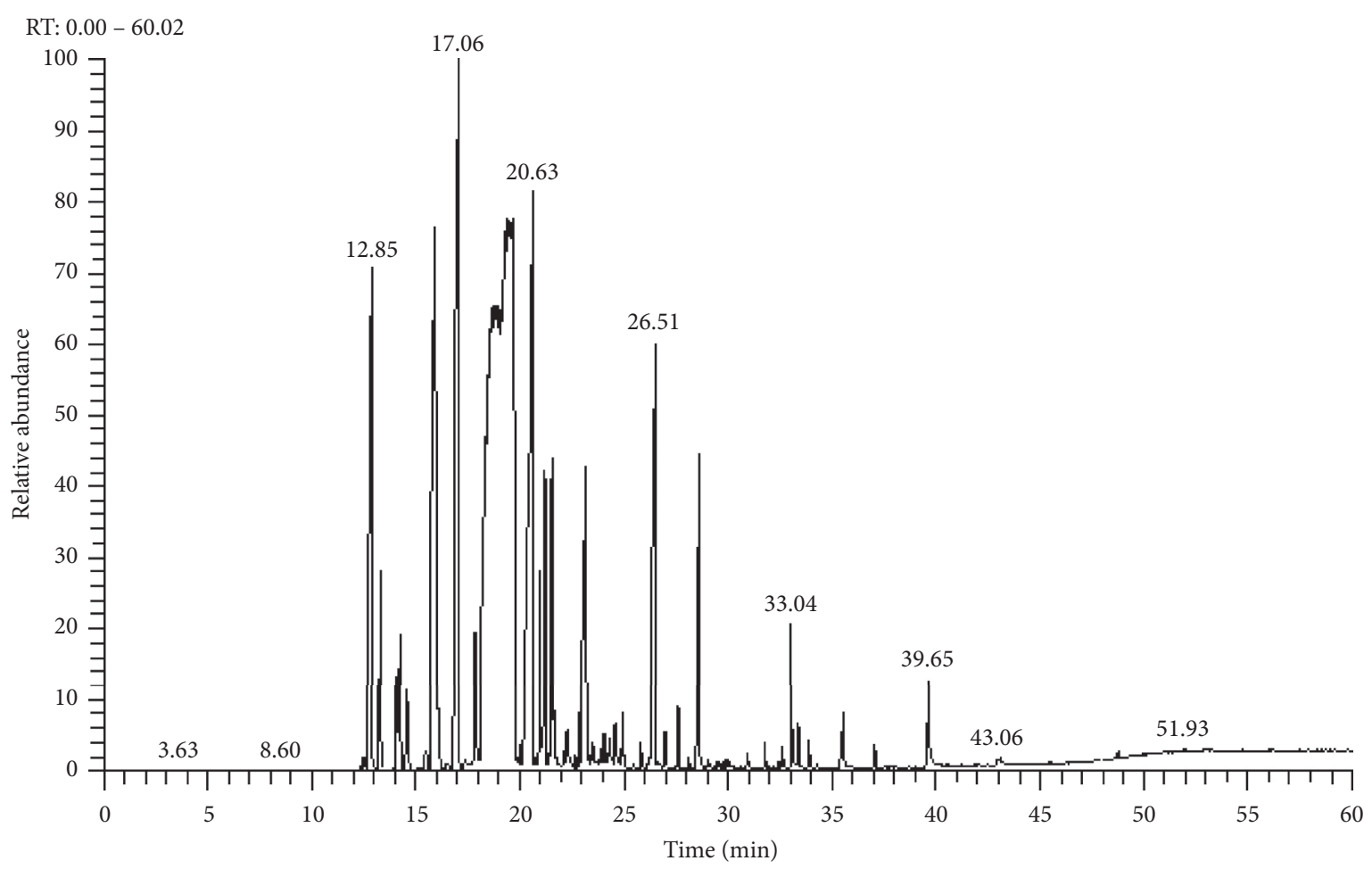

FIGURE 1: Chromatogram of essential oil from L. nobilis flowers.

TABLE 1: Phytochemical analysis of essential oil from L. nobilis flowers.

\begin{tabular}{|c|c|c|c|c|c|c|c|}
\hline Peak & Compounds & $\begin{array}{l}\text { Chemical } \\
\text { formula }\end{array}$ & $* \mathrm{RT}(\min )$ & $* * \mathrm{KI}$ & Identification & Area $(\%)$ & $* * *$ Mass range $(m / z)$ \\
\hline 1 & Terpinolene & $\mathrm{C} 10 \mathrm{H} 16$ & 12.85 & 1042 & GC-MS, IK & 0.10 & $(136), 93,121,91,136,79,77,105,39,41,107$ \\
\hline 2 & Germacradienol & $\mathrm{C} 2 \mathrm{H} 6 \mathrm{O}$ & 15.75 & 1476 & GC-MS, IK & 6.13 & $(204), 161,105,91,41,119,79,81,93,77,80$ \\
\hline 3 & 1,8-Cineole & $\mathrm{C} 10 \mathrm{H} 18 \mathrm{O}$ & 17.06 & 1059 & GC-MS, IK & 45.01 & $(154), 43,93,81,71,69,84,68,108,41,55$ \\
\hline 4 & $\alpha$-Phellandrene & $\mathrm{C} 10 \mathrm{H} 16$ & 19.45 & 964 & GC-MS, IK & 1.02 & $(136), 93,77,91,136,79,94,41,80,92,39$ \\
\hline 5 & $\alpha$-Terpinene & $\mathrm{C} 10 \mathrm{H} 16$ & 20.46 & 1112 & GC-MS, IK & 2.69 & $(154), 71,111,93,43,86,41,69,55,68,154$ \\
\hline 6 & $\alpha$-Caryophyllene & $\mathrm{C} 15 \mathrm{H} 24$ & 20.63 & 1494 & GC-MS, IK & 7.54 & $(136), 93,77,91,136,79,94,41,80,92,93$ \\
\hline 7 & Germacrene D & $\mathrm{C} 15 \mathrm{H} 24$ & 21.60 & 1505 & GC-MS, IK & 3.14 & $(204), 161,105,91,41,119,79,81,93,77,27$ \\
\hline 8 & Linalool & $\mathrm{C} 10 \mathrm{H} 18 \mathrm{O}$ & 22.14 & 1093 & GC-MS, IK & 1.04 & $(136), 93,41,69,39,91,77,79,27,92,53$ \\
\hline 9 & $\alpha$-Terpineol & $\mathrm{C} 10 \mathrm{H} 18 \mathrm{O}$ & 25.10 & 1177 & GC-MS, IK & 1.05 & $(154), 59,93,121,136,81,43,68,95,67,41$ \\
\hline 10 & Limonene & $\mathrm{C} 10 \mathrm{H} 16$ & 26.51 & 1018 & GC-MS, IK & 4.69 & $(136), 93,92,91,77,79,41,39,121,27,105$ \\
\hline 11 & Sabinene & $\mathrm{C} 10 \mathrm{H} 16$ & 27.56 & 983 & GC-MS, IK & 3.01 & $(136), 93,41,91,77,79,39,27,69,94,43$ \\
\hline 12 & $\alpha$-Pinene & $\mathrm{C} 10 \mathrm{H} 16$ & 28.50 & 938 & GC-MS, IK & 3.04 & $(153), 71,41,43,93,55,69,80,39,121,27$ \\
\hline 13 & Methyl-eugenol & $\mathrm{C} 11 \mathrm{H} 14 \mathrm{O} 2$ & 30.03 & 1376 & GC-MS, IK & 1.11 & $(178), 178,136,147,103,91,107,179,151,41,77$ \\
\hline 14 & $\alpha$-Phellandrene & $\mathrm{C} 10 \mathrm{H} 16$ & 37.45 & 954 & GC-MS, IK & 1.28 & $(136), 93,77,91,136,79,94,41,80,92,39$ \\
\hline 15 & $\beta$-Pinene & $\mathrm{C} 10 \mathrm{H} 16$ & 38.57 & 924 & GC-MS, IK & 3.01 & $(136), 93,91,136,121,77,92,79,43,41,105$ \\
\hline 16 & Myrcene & $\mathrm{C} 10 \mathrm{H} 16$ & 40.40 & 948 & GC-MS, IK & 1.56 & $(136), 41,93,69,39,27,53,79,77,67,91$ \\
\hline 17 & (Z)-3-Hexenol & $\mathrm{C} 6 \mathrm{H} 12 \mathrm{O}$ & 41.24 & 862 & GC-MS, IK & 0.85 & $(100), 67,41,39,55,82,31,69,53,54,27$ \\
\hline 18 & Camphene & $\mathrm{C} 10 \mathrm{H} 16$ & 42.07 & 933 & GC-MS, IK & 0.15 & $(136), 93,79,91,77,41,121,80,94,107,39$ \\
\hline 19 & Caryophyllene oxide & $\mathrm{C} 10 \mathrm{H} 18 \mathrm{O}$ & 43.50 & 1506 & GC-MS, IK & 0.42 & $(220), 43,41,79,93,91,95,69,55,67,81$ \\
\hline 20 & p-Cymene & $\mathrm{C} 10 \mathrm{H} 14$ & 44.80 & 1032 & GC-MS, IK & 0.10 & $(134), 119,134,91,120,117,41,77,39,65,115$ \\
\hline 21 & Carene & $\mathrm{C} 10 \mathrm{H} 16$ & 48.04 & 973 & GC-MS, IK & 0.01 & $(136), 93,41,91,77,79,39,27,69,94,43$ \\
\hline 22 & 3-Carene & $\mathrm{C} 10 \mathrm{H} 16$ & 49.13 & 1004 & GC-MS, IK & 0.98 & $(136), 93,91,79,77,92,121,80,136,94,105$ \\
\hline 23 & Isobornyl acetate & $\mathrm{C} 12 \mathrm{H} 20 \mathrm{O} 2$ & 50.26 & 1262 & GC-MS, IK & 0.25 & $(196), 95,43,121,93,136,41,108,110,55,82$ \\
\hline 24 & $\beta$-Elemol & $\mathrm{C} 15 \mathrm{H} 26 \mathrm{O}$ & 55.34 & 1545 & GC-MS, IK & 0.10 & $(208), 208,193,209,91,65,133,79,77,177,105$ \\
\hline \multirow[t]{3}{*}{25} & $\alpha$-Thujene & $\mathrm{C} 10 \mathrm{H} 16$ & 51.25 & 973 & GC-MS, IK & 0.65 & $(136), 93,41,91,77,79,39,27,69,94,43$ \\
\hline & & Total & 92.07 & & & & \\
\hline & & Yields (\%) & 1.06 & & & & \\
\hline
\end{tabular}

$*$ RT: retention time obtained by chromatogram (Figure 1$). * *$ KI: Kovats index was determined by GC-FID on a CP-Sil $5 \mathrm{CB}$ column. $* * *$ Mass range $(m /$ $z$ ): determined by mass spectrometry (PlarisQ). 
TAвLE 2: Minimum inhibitory concentration (MIC) of essential oil from L. nobilis flowers (mg/mL).

\begin{tabular}{lcc}
\hline Microorganisms & Disc diffusion assay (inhibition zone in mm) & MIC $(\mathrm{mg} / \mathrm{mL})$ \\
\hline Aspergillus clavatus & $19.25 \pm 0.12$ & 0.05 \\
Aspergillus niger & $14.35 \pm 0.04$ & 0.14 \\
Chaetomium globosum & $12.45 \pm 0.34$ & 0.18 \\
Cladosporium cladosporioides & $8.25 \pm 0.02$ & 0.25 \\
Myrothecium verrucaria & $7.35 \pm 0.35$ & 0.29 \\
Penicillium citrinum & $7.15 \pm 0.01$ & 0.36 \\
Trichoderma viride & $6.05 \pm 0.03$ & 0.46 \\
\hline
\end{tabular}

Disc diameter $6 \mathrm{~mm}$ average of two consecutive trials. MIC: minimal inhibitory concentration; concentration range: $0.05-0.46 \mathrm{mg} / \mathrm{mL}$.

TABLE 3: $\mathrm{IC}_{50}$ values of DPPH radical scavenging activity.

\begin{tabular}{lr}
\hline & $\mathrm{IC}_{50}(\mu \mathrm{g} / \mathrm{ml})$ \\
\hline Essential oil & $82.01 \pm 0.002$ \\
BHT & $7.71 \pm 0.0001$ \\
Ascorbic acid & $1.16 \pm 0.0001$ \\
\hline
\end{tabular}



FIgURE 2: Total antioxidant capacity of different volumes of essential oil from L. nobilis flowers. Results are expressed as mg AAE/g.

4.2. Antifungal Activity. The antimicrobial activity of essential oil from $L$. nobilis flowers against microorganisms was determined qualitatively and quantitatively. In Table 2, we report the widths $(\mathrm{mm})$ of the inhibition halos exhibited by the essential oil against different pathogens (A. clavatus, A. niger, C. globosum, C. cladosporioides, M. verrucaria, $P$. citrinum, and $T$. viride). The results indicate that the essential oil of $L$. nobilis flowers exhibits strong antifungal activity especially against $A$. clavatus, $A$. niger, and C. globosum. Previous studies have reported the antimicrobial activity of members of the genus Laurus. This activity might be due to 1.8 -cineole and $\alpha$-caryophyllene and their precursors [62-65]. In fact, 1.8-cineole alone has been shown to exhibit a better antifungal activity than the whole essential oil [66].

The antifungal activities, in general, have been mainly explained through terpenes with aromatic rings and phenolic hydroxyl groups able to form hydrogen bonds with active sites of the target enzymes, although other active terpenes, as well as alcohols, aldehydes, and esters can contribute to the overall antifungal effect of essential oils [67]. Pinene-type monoterpene hydrocarbons are wellknown chemicals having antimicrobial properties [68]. The difference in antifungal efficacy is a result of higher concentrations of the same chemical or a result of different chemical composition between plants. Several studies have been conducted to understand the mechanism of action of plant extracts and essential oils; however, it is still unclear [69]. It has been suggested that components of the essential oils and extracts cross the cell membrane interact with the enzymes and proteins of the membrane producing a flux of protons towards the cell exterior, causing cell death [66]. Pinene-type monoterpene hydrocarbons ( $\alpha$-pinene and $\beta$-pinene), limonene, and linalool are well-known chemicals having antimicrobial properties $[67,70,71]$.

\subsection{Antioxidant Activity}

4.3.1. DPPH Radical Scavenging Activity. The strong free radical scavenging capacity of the essential oil of $L$. nobilis may be due to different chemical compounds present in the oil, especially the relatively high percentage of 1.8-cineole (45.01\%) and $\alpha$-caryophyllene (7.54\%), although other compounds such as germacradienol (6.13\%), limonene (4.69\%), $\alpha$-pinene (3.04\%), and germacrene D (3.14\%) may be involved.

Furthermore, the antioxidant activity may be altered by synergistic and antagonistic effects between some components of the essential oil [72]. The synergistic activity of 1.8cineole and $\alpha$-caryophyllene has been documented [73]. Our 
results are in accordance with those found by other researchers [74-77], further confirming the antioxidant capacity of essential oil from $L$. nobilis and its potential as a natural preservative in food and pharmaceutical industries.

4.3.2. Total Antioxidant Activity. The essential oil of L. nobilis flowers exhibited higher total antioxidant capacity compared to previous reports [72], and this can be explained by the variation in the chemical composition of the essential oil due to the difference of regions affected by environmental factors, and also by the redox power of this substance and its electron/hydrogen exchange capacity.

These results represent a basis for further studies that could lead to the utilisation of this essential oil as a natural antioxidant agent, in both food and pharmaceutical fields.

\section{Conclusion}

This study revealed the chemical composition of the essential oil of $L$. nobilis flowers originated from the Middle Atlas mountains in Morocco. The essential oil was characterised by GC-MS and GC-FID, and twenty-five volatile compounds were identified which made up $92.07 \%$ of the total essential oil. The essential oil yield of the studies was $1.06 \%$, and the major constituents were 1.8-cineole, $\alpha$-caryophyllene, and germacradienol (6.13\%). The essential oil of $L$. nobilis flowers exhibited important antioxidant and antifungal activities especially against $A$. clavatus, A. niger, and C. globosum, suggesting its potential as a source of antifungal compounds identification. However, further studies should be conducted to evaluate its efficacy against phytopathogenic fungi under field conditions.

These results constitute an important step in the search for biologically active natural substances. Additional tests will be necessary to find formulations for the use of the essential oil from L. nobilis flowers in food, pharmaceutical, and cosmetic industries.

\section{Data Availability}

The data used to support the findings of this study are available from the corresponding author upon request.

\section{Conflicts of Interest}

The authors declare no conflicts of interest.

\section{References}

[1] B. P. Pandey, R. Thapa, and A. Upreti, "Chemical composition, antioxidant and antibacterial activities of essential oil and methanol extract of Artemisia vulgaris and Gaultheria fragrantissima collected from Nepal," Asian Pacific Journal of Tropical Medicine, vol. 10, no. 10, pp. 952-959, 2017.

[2] R. Sepahvand, B. Delfan, S. Ghanbarzadeh, M. Rashidipour, G. H. Veiskarami, and J. Ghasemian-Yadegari, "Chemical composition, antioxidant activity and antibacterial effect of essential oil of the aerial parts of Salvia sclareoides," Asian Pacific Journal of Tropical Medicine, vol. 7, pp. S491-S496, 2014.
[3] A. Barla, G. Topcu, S. Oksuz, G. Tumen, and D. Kingston, "Identification of cytotoxic sesquiterpenes from Laurus nobilis L." Food Chemistry, vol. 104, no. 4, pp. 1478-1484, 2007.

[4] G. Buchbauer, "The detailed analysis of essential oils leads to the understanding of their properties," Perfumer \& Flavorist, vol. 25, pp. 64-67, 2000.

[5] M. Aqili Khorasanin, Collection of Drugs (Materia Media), Enqelab-e-Eslami Publishing and Educational Organization, Tehran, Iran, 1992.

[6] A. Zargari, Medicinal Plants, Vol. 4, Tehran University Press, Tehran, Iran, 1990.

[7] M. Chmit, H. Kanaan, J. Habib, M. Abbass, A. Mcheik, and A. Chokr, "Antibacterial and antibiofilm activities of polysaccharides, essential oil, and fatty oil extracted from Laurus nobilis growing in Lebanon," Asian Pacific Journal of Tropical Medicine, vol. 7, pp. S546-S552, 2014.

[8] A. Caredda, B. Marongiu, S. Porcedda, and C. Soro, "Supercritical carbon dioxide extraction and characterization of Laurus nobilis essential oil," Journal of Agricultural and Food Chemistry, vol. 50, no. 6, pp. 1492-1496, 2002.

[9] F. Conforti, G. Statti, D. Uzunov, and F. Menichini, "Comparative chemical composition and antioxidant activities of wild and cultivated Laurus nobilis L. leaves and Foeniculum vulgare subsp. piperitum (Ucria) Coutinho seeds," Biological \& Pharmaceutical Bulletin, vol. 29, no. 10, pp. 2056-2064, 2006.

[10] T. Özek, F. Demirci, K. H. C. Baser, and G. Tümen, "Composition of the essential oil of Coridothymus capitatus (L.) reichb. fil. from Turkey," Journal of Essential Oil Research, vol. 7, no. 3, pp. 309-312, 1995.

[11] M. Sayyah, J. Valizadeh, and M. Kamalinejad, "Anticonvulsant activity of the leaf essential oil of Laurus nobilis against pentylenetetrazole- and maximal electroshock-induced seizures," Phytomedicine, vol. 9, no. 3, pp. 212-216, 2002.

[12] R. Abu-Dahab, V. Kasabri, and F. U. Afifi, "Evaluation of the volatile oil composition and antiproliferative activity of Laurus nobilis L. (Lauraceae) on breast cancer cell line models," Records of Natural Products, vol. 8, pp. 136-147, 2014.

[13] L. R. Peixoto, P. L. Rosalen, G. L. S. Ferreira et al., "Antifungal activity, mode of action and anti-biofilm effects of Laurus nobilis Linnaeus essential oil against Candida spp," Archives of Oral Biology, vol. 73, pp. 179-185, 2017.

[14] A. Simić, M. D. Soković, M. Ristić, S. Grujić-Jovanović, J. Vukojević, and P. D. Marin, "The chemical composition of some Lauraceae essential oils and their antifungal activities," Phytotherapy Research, vol. 18, no. 9, pp. 713-717, 2004.

[15] S. Burt, "Essential oils: their antibacterial properties and potential applications in foods-a review," International Journal of Food Microbiology, vol. 94, no. 3, pp. 223-253, 2004.

[16] B. Ozcan, M. Esen, S. Kemal, A. Coleri, and M. Caliskan, "Effective antibacterial and antioxidant properties of methanolic extract of Laurus nobilis seed oil," Journal of Environmental Biology, vol. 31, no. 5, pp. 637-641, 2010.

[17] E. Y. Qnais, F. A. Abdulla, E. G. Kaddumi, and S. S. Abdalla, "Antidiarrheal activity of Laurus nobilis L. leaf extract in rats," Journal of Medicinal Food, vol. 15, no. 1, pp. 51-57, 2012.

[18] L. Caputo, F. Nazzaro, L. Souza et al., "Laurus nobilis: composition of essential oil and its biological activities," Molecules, vol. 22, no. 6, p. 930, 2017.

[19] P. A. Riabov, D. Micić, R. B. Božović et al., "The chemical, biological and thermal characteristics and gastronomical perspectives of Laurus nobilis essential oil from different 
geographical origin," Industrial Crops and Products, vol. 151, Article ID 112498, 2020.

[20] G. Milhau, A. Valentin, F. Benoit et al., "In vitro antimalarial activity of eight essential oils," Journal of Essential Oil Research, vol. 9, no. 3, pp. 329-333, 1997.

[21] M. Sylvestre, A. Pichette, A. Longtin, F. Nagau, and J. Legault, "Essential oil analysis and anticancer activity of leaf essential oil of Croton flavens L. from Guadeloupe," Journal of Ethnopharmacology, vol. 103, no. 1, pp. 99-102, 2006.

[22] M. Faid, K. Bakhy, M. Anchad, and A. Tantaoui-Elaraki, "Almond paste: physicochemical and microbiological characterization and preservation with sorbic acid and cinnamon," Journal of Food Protection, vol. 58, no. 5, pp. 547-550, 1995.

[23] K. Mahnaz, F. Alireza, V. Hassan, S. Mahdi, A. M. Reza, and H. Abbas, "Larvicidal activity of essential oil and methanol extract of Nepeta menthoides against malaria vector Anopheles stephensi," Asian Pacific Journal of Tropical Medicine, vol. 5, no. 12, pp. 962-965, 2012.

[24] M. Z. Salem, H. M. Ali, N. A. El-Shanhorey, and A. AbdelMegeed, "Evaluation of extracts and essential oil from Callistemon viminalis leaves: antibacterial and antioxidant activities, total phenolic and flavonoid contents," Asian Pacific Journal of Tropical Medicine, vol. 6, no. 10, pp. 785-791, 2013.

[25] N. Hamamouch, "Use of ethnomedicinal plants by the people living in the middle atlas mountains in Morocco," Medicinal and Aromatic Plants, vol. 9, p. 349, 2020.

[26] G. B. Avanço, F. D. Ferreira, N. S. Bomfim et al., "Curcuma longa L. essential oil composition, antioxidant effect, and effect on Fusarium verticillioides and fumonisin production," Food Control, vol. 73, pp. 806-813, 2017.

[27] J. F. Clevenger, "Apparatus for volatile oil determination, description of new type," American Perfumer \& Essential Oil Review, vol. 17, no. 4, pp. 345-349, 1928.

[28] P. R. Adam, Identification of Essential Oil Components by Gas Chromatography/Mass Spectrometry, Allured Publishing Corporation, Carol Stream, IL, USA, 2007.

[29] A. Adiguzel, O. Hakan, K. Hamdullah, and C. Bulent, "Screening of antimicrobial activity of essential oil and methanol extract of Satureja hortensis on food borne bacteria and fungi," Czech Journal of Food Sciences, vol. 25, no. 2, pp. 81-89, 2002.

[30] H. I. Gul, T. Ojanen, and O. Hänninen, "Antifungal evaluation of Bis Mannich bases derived from acetophenones and their corresponding piperidinols and stability studies," Biological \& Pharmaceutical Bulletin, vol. 25, no. 10, pp. 13071310, 2002.

[31] P. Murray, E. Baron, M. Pfaller, F. Tenover, and R. Yolke, Manual of Clinical Microbiology, ASM, Washington, DC, USA, 6th edition, 1995.

[32] A. El Moussaoui, F. Z. Jawhari, A. M. Almehdi et al., "Antibacterial, antifungal and antioxidant activity of total polyphenols of Withania frutescens L." Bioorganic Chemistry, vol. 93, Article ID 103337, 2019.

[33] P. Maskovic, N. Manojlovic, A. Mandic et al., "Phytochemical screening and biological activity of extracts of plant species Halacsya sendtneri (Boiss.) Dörfl," Chemical Industry, vol. 66, no. 1, pp. 43-51, 2012.

[34] S. Abdillah, R. M. Tambunan, Y. Farida, N. M. D. Sandhiutami, and R. M. Dewi, "Phytochemical screening and antimalarial activity of some plants traditionally used in Indonesia," Asian Pacific Journal of Tropical Disease, vol. 5, no. 6, pp. 454-457, 2015.
[35] A. M. Saab, R. Tundis, M. R. Loizzo et al., "Antioxidant and antiproliferative activity of Laurus nobilis L. (Lauraceae) leaves and seeds essential oils against K562 human chronic myelogenous leukaemia cells," Natural Product Research, vol. 26, no. 18, pp. 1741-1745, 2012.

[36] B. Nabiha, E. O. Abdelfateh, K. Faten, W. J. Paul, M. Michel, and C. M. Moncef, "Chemical composition and antioxidant activity of Laurus nobilis floral buds essential oil," Journal of Essential Oil Bearing Plants, vol. 12, no. 6, pp. 694-702, 2009.

[37] O. Ciftci, I. Ozdemir, S. Tanyildizi, S. Yildiz, and H. Oguzturk, "Antioxidative effects of curcumin, $\beta$-myrcene and 1,8-cineole against 2,3,7,8-tetrachlorodibenzo-p-dioxin-induced oxidative stress in rats liver," Toxicology and Industrial Health, vol. 27, no. 5, pp. 447-453, 2011.

[38] P. Prieto, M. Pineda, and M. Aguilar, "Spectrophotometric quantitation of antioxidant capacity through the formation of a phosphomolybdenum complex: specific application to the determination of vitamin E," Analytical Biochemistry, vol. 269, no. 2, pp. 337-341, 1999.

[39] E. Derwich, Z. Benziane, and A. Boukir, "Chemical composition and insecticidal activity of essential oils of three plants Artemisia sp: Artemisia herba-alba, Artemisia absinthium and Artemisia pontica (Morocco)," Electronic Journal of Environmental, Agricultural and Food Chemistry, vol. 8, no. 11, pp. 1202-1211, 2009.

[40] E. Derwich, A. Manar, Z. Benziane, and A. Boukir, "GC/MS analysis and in vitro antibacterial activity of the essential oil isolated from leaf of Pistacia lentiscus growing in Morocco," World Applied Sciences Journal, vol. 8, no. 10, pp. 1267-1276, 2010.

[41] P. Edward, V. Claus, E. Tyler, and R. Brady, Pharmacognosy, Lea \& Febiger, Philadelphia, PA, USA, 6th edition, 1985.

[42] O. Islaka, N. Olawore, and K. Adeleke, "Chemical composition of the essential oils from the leaves of three Eucalyptus species growing in Nigeria," Journal of Essential Oil Research, vol. 15, no. 5, pp. 297-301, 2003.

[43] E. Derwich, Z. Benziane, R. Chabir, and A. Bouseta, "Antifungal activity and gas chromatography coupled with mass spectrometry (GC-MS) leaf oil analysis of essential oils extracted from Eucalyptus globulus (Myrtaceae) of north centre region of Morocco," African Journal of Pharmacy and Pharmacology, vol. 7, no. 19, pp. 1157-1162, 2013.

[44] S. Yu-Chang, H. Chen-Lung, W. Eugene I-Chen, and C. Shang-Tsen, "Antifungal activities and chemical compositions of essential oils from leaves of four eucalypts," Taiwan Journal of Forest Science, vol. 21, no. 1, pp. 49-61, 2006.

[45] E. Dellacassa, P. Menéndez, P. Moyna, and E. Soler, "Chemical composition of Eucalyptus essential oils grown in Uruguay," Flavour and Fragrance Journal, vol. 5, no. 2, pp. 91-95, 1990.

[46] S. Benayache, F. Benayache, S. Benyahia, J.-C. Chalchat, and R.-P. Garry, "Leaf oils of some Eucalyptus species growing in Algeria," Journal of Essential Oil Research, vol. 13, no. 3, pp. 210-213, 2001.

[47] M. Dethier, A. Nduwimana, Y. Cordier, C. Menut, and G. Lamaty, "Aromatic plants of tropical central Africa XVI studies on essential oils of five Eucalyptus species grown in Burundi," Journal of Essential Oil Research, vol. 6, no. 5, pp. 469-473, 1994.

[48] K. Cimanga, S. Apers, T. de Bruyne et al., "Chemical composition and antifungal activity of essential oils of some aromatic medicinal plants growing in the Democratic Republic of Congo," Journal of Essential Oil Research, vol. 14, no. 5, pp. 382-387, 2002. 
[49] F. P. Pagula, K. H. C. Baser, and M. Kürkçüoglu, “Essential oil composition of Eucalyptus camaldulensis Dehn from Mozambique," Journal of Essential Oil Research, vol. 12, no. 3, pp. 333-335, 2000.

[50] D. Tsiri, O. Kretsi, I. B. Chinou, and C. G. Spyropoulos, "Composition of fruit volatiles and annual changes in the volatiles of leaves of Eucalyptus camaldulensis Dehn. growing in Greece," Flavour and Fragrance Journal, vol. 18, no. 3, pp. 244-247, 2003.

[51] H. Bendaoud, J. Bouajila, and A. Rhouma, "GC/MS analysis and antimicrobial and antioxidant activities of essential oil of Eucalyptus radiata," Journal of the Science of Food and Agriculture, vol. 89, no. 8, pp. 1292-1297, 2009.

[52] G. Sacchetti, S. Maietti, M. Muzzoli et al., "Comparative evaluation of 11 essential oils of different origin as functional antioxidants, antiradicals and antimicrobials in foods," Food Chemistry, vol. 91, no. 4, pp. 621-632, 2005.

[53] I. Dadalioglu and G. Evrendilek, "Chemical compositions and antibacterial effects of essential oils of Turkish oregano (Origanum minutiflorum), bay (Laurus nobilis), Spanish lavender (Lavandula stoechas L) and fennel (foeniculum vulgare) on common foodborne pathogens," Journal of Agricultural and Food Chemistry, vol. 52, pp. 8255-8260, 2004.

[54] L. Ntezurubanza, Les Huiles Essentielles du Rwanda, UQUAC, Québec, Canada, 2000.

[55] A. Kilic, H. Kollmannsberger, and S. Nitz, "Glycosidically bound volatiles and flavor precursors in Laurus nobilis L." Journal of Agricultural and Food Chemistry, vol. 53, no. 6, pp. 2231-2235, 2005.

[56] L. Zheng-kui, H. Ying-fang, G. Guo-ping, and G. Yu-hong, "Chemical constituents of the essential oils from the leaves of Laurus nobilis and tendency in changes of the constituents month by month," Acta Botanica Sinica, vol. 32, pp. 878-882, 1990.

[57] N. Bouzouita, A. Nafti, M. M. Chaabouni et al., "Chemical composition of Laurus nobilis oil from Tunisia," Journal of Essential Oil Research, vol. 13, no. 2, pp. 116-117, 2001.

[58] H. Fidan, G. Stefanova, I. Kostova et al., "Chemical composition and antimicrobial activity of Laurus nobilis L. essential oils from Bulgaria," Molecules, vol. 24, no. 4, p. 804, 2019.

[59] G. Flamini, M. Tebano, P. L. Cioni, L. Ceccarini, A. S. Ricci, and I. Longo, "Comparison between the conventional method of extraction of essential oil of Laurus nobilis L. and a novel method which uses microwaves applied in situ, without resorting to an oven," Journal of Chromatography A, vol. 1143, no. $1-2$, pp. $36-40,2007$.

[60] H. Hokwerda, R. Bos, D. Tattje, and T. Malingre, "Composition of essential oils of Laurus nobilis, L. nobilis var. angustifolia and Laurus azorica," Planta Medica, vol. 44, no. 2 , pp. 116-119, 1982.

[61] H. Marzouki, A. Khaldi, R. Chamli et al., "Biological activity evaluation of the oils from Laurus nobilis of Tunisia and Algeria extracted by supercritical carbon dioxide," Natural Product Research, vol. 23, no. 3, pp. 230-237, 2009.

[62] A. Sivropoulou, C. Nikolaou, E. Papanikolaou, S. Kokkini, T. Lanaras, and M. Arsenakis, "Antimicrobial, cytotoxic and antiviral activities of Salvia fruticosa, essential oil," Journal of Agricultural and Food Chemistry, vol. 45, no. 8, pp. 3197-3201, 1997.

[63] S. Felice, F. Carmen, D. Andrea, and Ö. Musa, "Chemical composition and antibacterial activity of the essential oil of a 1,8-cineole chemotype of Mentha aquatica L. growing wild in
Turkey," Journal of Essential Oil-Bearing Plants (JEOP), vol. 8, no. 2, pp. 148-153, 2013.

[64] B. Damjanovic-Vratnica, T. Dakov, C. Sukovi, and J. Damjanovic, "Antimicrobial effect of essential oil isolated from Eucalyptus globulus Labill. from Montenegro," Czech Journal of Food Sciences, vol. 29, no. 3, pp. 277-284, 2011.

[65] Y. Matsuzaki, T. Tsujisawa, T. Nishihara, M. Nakamura, and Y. Kakinoki, "Antifungal activity of chemotype essential oils from rosemary against Candida albicans," Open Journal of Stomatology, vol. 3, no. 2, pp. 176-182, 2013.

[66] I. Dammak, Z. Hamdi, S. Kammoun El Euch et al., "Evaluation of antifungal and anti-ochratoxigenic activities of salvia officinalis, Lavandula dentata and Laurus nobilis essential oils and a major monoterpene constituent 1,8-cineole against Aspergillus carbonarius," Industrial Crops and Products, vol. 128, pp. 85-93, 2019.

[67] N. Belletti, M. Ndagihimana, C. Sisto, R. Guerzoni, R. Lanciotti, and F. Gardini, "Evaluation of the antimicrobial activity of Citrus essences on Saccharomyces cerevisae," Journal of Agricultural and Food Chemistry, vol. 52, pp. 6932-6938, 2004.

[68] H. Dorman and S. Deans, "Antimicrobial agents from plants: antibacterial activity of plant volatile oils," Journal of Applied Microbiology, vol. 88, pp. 308-316, 2008.

[69] M. Omidbeygi, M. Bazegar, Z. Hamidi, and H. Nafhdibadi, "Antifungal activity of thyme, summer savory and clove essential oils against Aspergillus flavus in liquid medium and tomato paste," Food Control, vol. 18, pp. 1518-1523, 2007.

[70] N. Filipowicz, M. Kamiński, J. Kurlenda, and M. Asztemborska, "Antibacterial and antifungal activity of juniper berry oil and its selected components," Phytotherapy Research, vol. 17, pp. 227-231, 2003.

[71] Y. Koji, T. Yamamoto, Y. Kawai, and N. Inoue, "Enhancement of antilisterial activity of essentials oil constituents by nisin and diglycerol fatty acid ester," Food Microbiology, vol. 21, no. 3, pp. 283-289, 2004.

[72] H. Guenane, A. Gherib, A. Carbonell-Barrachina et al., "Minerals analysis, antioxidant and chemical composition of extracts of Laurus nobilis from southern Algeria," Journal of Materials and Environmental Science, vol. 7, no. 11, pp. 4253-4261, 2016.

[73] F. A. Santos and V. S. Rao, "Antiinflammatory and antinociceptive effects of 1,8-cineole a terpenoid oxide present in many plant essential oils," Phytotherapy Research, vol. 14, no. 4, pp. 240-244, 2000.

[74] S. Santoyo, R. Lloría, L. Jaime, E. Ibáñez, F. J. Señoráns, and G. Reglero, "Supercritical fluid extraction of antioxidant and antimicrobial compounds from Laurus nobilis L. chemical and functional characterization," European Food Research and Technology, vol. 222, pp. 565-571, 2006.

[75] L. Cherrat, L. Espina, M. Bakkali, D. García-Gonzalo, R. Pagán, and A. Laglaouia, "Chemical composition and antioxidant properties of Laurus nobilis L. and Myrtus communis L. essential oils from Morocco and evaluation of their antimicrobial activity acting alone or in combined processes for food preservation," Journal of the Science of Food and Agriculture, vol. 94, pp. 1197-1204, 2014.

[76] S. Bounatirou, S. Smiti, M. Miguel et al., "Chemical composition, antioxidant and antimicrobial activities of the essential oils isolated from Tunisian thymus capitus Hoff and Link," Food Chemistry, vol. 105, pp. 146-155, 2007.

[77] N. Celikel and G. Kavas, "Antimicrobial properties of some essential oils against some pathogenic microorganisms," Czech Journal of Food Sciences, vol. 26, pp. 174-181, 2008. 